\title{
Two new species belonging to the genus Boettcherisca R.-D. from Lesser Sunda Islands in Indonesia ${ }^{1)}$
}

\author{
Rokuro KANO* and Satoshi SHINONAGA* \\ * Department of Medical Zoology, Faculty of Medicine, Tokyo Medical and \\ Dental University, Tokyo 113, Japan
}

(Received : May 9, 1977)

\begin{abstract}
Two new species belonging to the genus Boettcherisca R.-D. were found from Lesser Sunda Islands in Indonesia. The adults of these two species were trapped in the forests using decayed meat and fishes as bait, and colonized in the laboratory. Both species are endemic species in each island, Flores and Timor. The descriptions and figures of these new species are given in this paper.
\end{abstract}

\section{DESCRIPTIONS}

\section{Boettcherisca koimani Kano and Shinonaga, new species (Fig. 1)}

Male. Body length 9-14 mm.

Head: Frons 0.18 of head width at narrowest part; frontal vitta black; frontal bristles 12-14 (rarely 10), lower 3 or 4 divergent; parafrontals and parafacials golden to silvery pruinose, with a row of fine hairs along eye margin; antennae black, length of 3 rd segment about $2 \mathrm{X}$ that of 2nd segment; arista black and feathered; face black covered with grayish pollen; vibrissae inserted at vibrissal angles; gena and metacephalon black with grayish pollen; gena with black hairs; metacephalon with long whitish hairs, but sometimes with 1-3 black hairs; occiput with white hairs; 3 rows of postocular setae black; palpi black and slender.

Thorax: Scutum grayish pollinose with 3 black longitudinal stripes ; ac $0+1$; $d c 5-$ $7+5-7$ (posterior 2 or 3 strong); ia $1+2-$ 3 ; prs $1 ; h 3$; ph 2 ; nt 4 ; sa 3 ; pa 2 ; aps

1) This study was supported by a grant-in-aid to the Tokyo Medical and Dental University Overseas Scientific Research Project 1973 from the Ministry of Education, Science and Culture of Japan.

* 加納六郎, 篠永 哲: 東京医科菌科大学医学部矤 動物学教室（尔113 東京都文京区湯島1-5-45）
$1 ; d s 1$; ls 3 (foremost one weak); st $1+1+$ 1 ; upper part of propleuron hairy; posterior half of prosternum hairy ; meso- and metathoracic spiracles dark brown.

Wing: Hyaline; basal and anterior parts yellowish brown; veins yellowish brown, but $m-m$ and apical $1 / 3$ of $r_{4+5}$ and $m_{1+2}$ dark brown; $r_{1}$ bare; $r_{4+5}$ with a row of fine setae between basal node and $r-m$; epaulet black; basicostal scale yellowish brown; upper and lower squamae yellowish brown; halteres dark brown.

Legs: Black; $t_{1}$ with $3 \mathrm{ad}$ and $1 \mathrm{pv} ; t_{2}$ with $1 a d, 1 v, 3 p l$ and $1 p d ; t_{3}$ with a row of $a d, 2 a v$, and $2 p d$, without long hairs.

Abdomen: Black with silvery checkered pattern; without median marginal bristles on 2nd and 3rd tergites; 4th and 5th tergites with strong marginal bristles; sternites black with silvery pollen, 1 st and 2nd genital tergites dark brown; genitalia as shown in Fig. 2. Anterior and posterior parameres same length.

Female. Body length $6-11 \mathrm{~mm}$. General characters similar to those of the male. Frons 0.26 of head width at narrowest part ; 2 proclinate and 1 reclinate fronto-orbital bristles present; outer vertical bristles well developed; genitalia as shown in Fig. 3.

Holotype: Male, Maumere $(10 \mathrm{~m}$ above the sea level), Flores Island, Indonesia, 1619 Dec. 1973, R. Kano.

Paratypes: $4 \hat{\delta}$ 스, 5 우우, same data as 


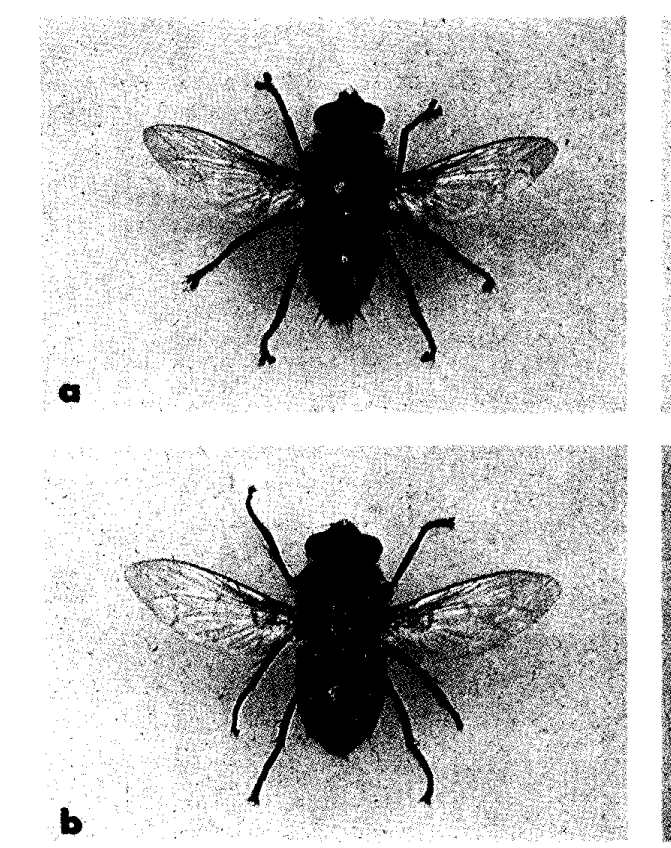

Fig. 1 a: Male of B. koimani n. sp. b: Female of B. koimani n. sp.

$\mathrm{c}$ : Male of B. timorensis n. sp. d: Female of B. timorensis n. sp.

holotype: 2 항, 4 우우, Lekebai $(900 \mathrm{~m}$ above the sea level), Flores, 17 Dec. 1973, R. Kano; 1ㅇ, 2우우, Wolowaru $(600 \mathrm{~m}$ above the sea level), Flores, 20 Dec. 1973, R. Kano; 50 \& 송, 50 우 우, these paratypes are colonized material from several females collected on 16-19 Dec. 1973 at Maumere, Flores Island. The colony has been kept in our laboratory since 1973.

Remarks: The present species differs from the other species belonging to the genus Boettcherisca in having the yellowish wing, except for B.timorensis. This species is easily differentiated from $B$. timorensis by the color of abdomen. The specific name of this species, koimani, is dedicated to Dr. Iskak Koiman, Director of Bio-Medical Research Center, who kindly cooperated with us in this study.

\section{Boettcherisca timorensis Kano and Shinonaga, new species (Fig. 1)}

Male. Body length $11-14 \mathrm{~mm}$.

Head: Frons 0.18 of head width at narrowest part; frontal vitta dark brown to black; frontal bristles 10 to 15 , lower 3 or 4 divergent; parafrontals and parafacials reddish brown and golden pruinose, with a row of fine hairs along eye margin; antennae black, length of $3 \mathrm{rd}$ segment about $2 \mathrm{X}$ that of 2nd segment ; arista black and feathered; face blackish brown with grayish pollen; vibrissae inserted at vibrissal angles; several strong bristles present on vibrissal angles; gena and metacephalon black with grayish pollen; gena with black hairs; metacephalon and occiput with whitish hairs; 3 rows of postocular setae black; palpi black and slender.

Thorax: Scutum gray or golden pollinose with 3 black longitudinal stripes; ac $0+1$; dc $5-7+5-7$ (posterior 2 or 3 strong); ia $1+2-3$; prs $1 ; h 3$; ph $2 ; n t 4 ; s a 3 ; p a$ 2 ; aps 1 ; ds 1 ; ls 3 (foremost one weak); st $1+1+1$; upper part of propleuron hairy ; posterior half of prosternum hairy; mesoand metathoracic spiracles blackish brown.

Wings: Hyaline; basal and anterior parts yellowish brown; $r_{1}$ bare; $r_{4+5}$ with fine setae between basal node and $r-m$; veins yellowish brown, but $m-m$ and apical $1 / 3$ of $r_{4+5}$ and $m_{1+2}$ dark brown; epaulet black; basicostal scale yellowish brown; upper and lower squamae yellowish brown; halteres brown.

Legs: Black; $t_{1}$ with 2-3ad, $1 p v ; t_{2}$ with $1 \mathrm{ad}, 1 v, 1 p d, 2-3 p l ; t_{3}$ with a row of $a d, 2 p d, 2-3 a v$, with many relatively long hairs on posteroventral surface.

Abdomen: Dorsal surfaces of 2 nd to 4 th tergites black, lateral parts of the tergites 


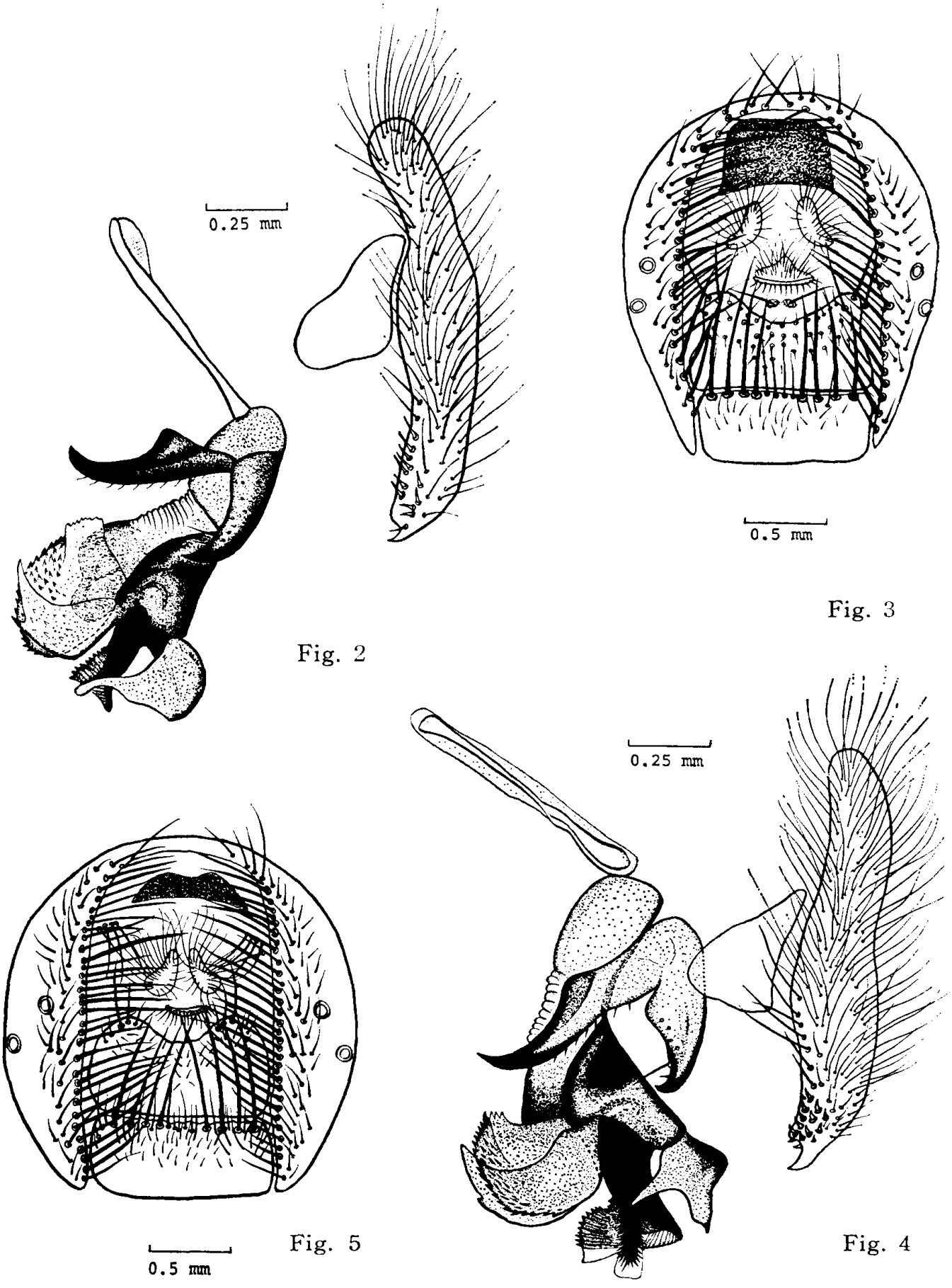

Fig. 2 Male genitalia of Boettcherisca koimani n. sp.

Fig. 3 Female genitalia of B. koimani n. sp.

Fig. 4 Male genitalia of $B$. timorensis n. sp.

Fig. 5 Female genitalia of $B$. timorensis n. sp.

reddish brown with golden pruinescence; 5 th tergite reddish brown and golden pruinose; 2nd and 3rd tergites without median marginal bristles; 4 th and 5 th tergites with strong bristles on posterior margins; ventral surfaces of tergites blackish brown; sternites blackish brown with black hairs; 1st and 2nd genital tergites light brown ; outer forceps and basal half of inner forceps brown, apical half of inner forceps black with strong short spines as shown in Fig. 4 ; genitalia as shown in Fig. 4; anterior and posterior parameres same length.

Female. Body length $9.5-13 \mathrm{~mm}$. General characters similar to those of the 
male. Frons 0.26 of head width at narrowest part; 2 proclinate and 1 reclinate fronto-orbital bristles present; outer vertical bristles well developed; genitalia as shown in Fig. 5.

Holotype: Male, Kupang, Timor Island, Indonesia, 15-18 Dec. 1973, S. Shinonaga.

Paratypes: $9 \hat{\delta} \hat{o}, 3$ 우우, same data as holotype : $50 \hat{\delta} \hat{\delta}, 50$ 우 우, these paratypes are colonized material from 2 females collected on 15-18 Dec. 1973 in Kupang, Timor Island by S. Shinonaga. The colony has been kept in our laboratory since 1973.

Remarks: This species is easily differentiated from the other Boettcheriscaspecies in color and absence of checkered pattern on abdominal tergites. This species was trapped in the forests near town using decayed meat and fishes as bait, but we could not find this species along seashore or market-places where Boettcherisca peregrina occurs.

The holotypes and a part of paratypes of these 2 new species are preserved in Bogor Museum, Indonesia and the other paratypes are deposited at the National Science Museum, Tokyo ; Bishop Museum, Honolulu ; British Museum (Natural History), London; and Smithsonian Institute, Washington, D.C.

\section{ACKNOWLEDGEMENTS}

We express sincere appreciation to Dr. J. Sulianti Saroso, Director of Institute of Health Research and Development, Department of Health, Jakarta, and Dr. Iskak Koiman, BioMedical Research Center, Department of Health, Jakarta, for their kind cooperation in this study; to Dr. Ben Mboi, IKES, Kupang, and
Dr. A. J. Berek, Maumere, and their assistants, for their kind assistance ; to Dr. Hiromu Kurahashi, Department of Medical Entomology, National Institute of Health, Tokyo, for his valuable suggestions; and to $\mathrm{Mr}$. Masatoshi Takaoka, Department of Medical Zoology, Tokyo Medical and Dental University, who is keeping the colonies of these new species.

\section{REFERENCES}

Fan, T. (1965): Key to the common synanthropic flies in China, Peking : 255-257 (in Chinese).

Kano, R., G. Field and S. Shinonaga (1967): Fauna Japonica, Sarcophagidae, (Insecta : Diptera), Biogeographical Soc. Japan, Tokyo, p. $16-20$.

Lopes, H.S. (1961): A contribution to the knowledge of the genus Boettcherisca Rohdendorf, 1937 (Diptera, Sarcophagidae), Mem. Inst. Oswaldo Cruz, 59(1): 69-82.

Rohdendorf, B. B. (1937): Faune de l'U.R.S.S. Insectes Diptères, $19(1)$ : 270-274.

Séguy, E. (1941): Encyclo. Entom., 21 : 131-132.

Senior-White, R., D. Aubertin and J. Smart (1940): Fauna Brit. Ind., Diptera, 6 : 272-274.

\section{摘 要}

インドネシア，小スンダ列島からの センチニクバェ属の 2 新種について

西南太平洋地域における衛生上重要な双翅類昆虫の動 物地理学的研究を行った際，1973 年 12 月にインドネシ ア，小スンダ列島のフローレス島およびチモール島にお いて,センチニクバェ属に属する 2 新種を見出した。これ ら 2 種はそれぞれの島の固有種で，フローレス島産のも のをコイマンセンチニクバェ, Boettcherisca koimani, チモール島のものをチモールセンチニクバエ B. timorensis と命名した。 これらの 2 種は各島の村に近い原生 林中で, 獣肉や魚肉に誘因された。しかしセンチニクバ エと異なり，海岸や市場では見出されなかった。 